\title{
Science theatre in teaching and popularizing the history of chemistry: The case of a theatrical play on Nobel-laureate A.l. Virtanen
}

Jan Jansson

Unit of Chemistry Teacher Education, Department of Chemistry, University of Helsinki, Finland • jan.jansson@tyk.fi

Maija Aksela

Unit of Chemistry Teacher Education, Department of Chemistry, University of Helsinki, Finland • maija.aksela@helsinki.fi

\begin{abstract}
The article discusses the significance of science theatre and the role of nature of science in it, as well as the significance of history of chemistry, and different methods for popularizing it and using it in teaching. The study includes two surveys ( $N=45$ and $N=126)$ conducted among the audiences of "Virtanen!" play, performed in 2011. The data was analyzed using content analysis. Based on the results, the history of science was mainly portrayed through the life of the protagonist of the play, and the play showed the human side of science to the audience. In addition, from the viewpoint of nature of science, the play emphasized the role of social interaction in science as well as the interaction between science and the society. According to the audiences, national expertise in chemistry should be emphasized more in order to increase interest towards the subject and also to promote national self-esteem. It was suggested that history of chemistry should be presented through different methods, such as science theater, school teaching, exhibitions, and documentary films, in future. Also, it was hoped that history would be included in chemistry teaching together with other chemistry contents, through historical portraits of scientists, in collaboration with other school subjects or as a separate lesson on history of science. Science theatre was found to be a good method to teach history of chemistry and nature of science, and to popularize chemistry.
\end{abstract}

\section{Introduction}

The knowledge of history of science is part of scientific literacy. The aim of this case study is to understand: (i) the significance of science theater in presenting history and nature of science, (ii) the significance of presenting Finnish history of science, and (iii) finding different methods for it. The focus of this study is on the significance of the Virtanen! play, performed in Finland during the International Year of Chemistry 2011. The study aims to discuss the results that can be achieved through science theatre.

\subsection{Science theatre and drama in popularization and teaching}

Science theatre always includes the dimensions of research and performance (Beck et al., 2011). On the research axis, the performance can be based on systematic research or on the use of secondary sources of information. The research axis is crossed by the performance axis, which can be used to evaluate the execution of the performance. At the beginning of this axis are: (i) the script-based performances for a certain purpose and (ii) limited audience with few theatrical means. These kinds of performances include: performances at conferences and performances developed in workshops. Going forward on the axis, the 
audiences get wider and the aesthetic goals of the performance are emphasized on the expense of authenticity.

There is only little research on the effects of science theatre earlier. Furthermore, there is no research on science theatre such as Virtanen! where the form resembles traditional theatre, in which the audience and performers are clearly separate. Examples of chemistryrelated theatre performances include "The amazing chemical circus" and "Atom surprise". Kerby et al. (2010) discuss the play "The amazing chemical circus" which is targeted to under 15-year-olds to increase interest and teach about chemistry contents. The team has designed the play employing the methods of theatrical script writing, like storytelling through questions, characters the audience can identify with, and impressive effects. Peleg et al. (2011) discuss the "Atom surprise" performance, which aims at teaching the structure of matter to 1-6 graders. The focus of the play is on two pupils' adventure inside matter. In both studies, it was noted that the pupils had learnt scientific contents during the performance and regarded watching it as a positive experience. Peleg et al. asked more specific questions on the interests of the pupils. Most of them liked the non-scientific contents that often involved theatrical effects. Both plays combined theatre and drama so that the pupils themselves played oxygen molecules, for example.

Wieringa et al. (2011) have studied science theatre in which the audience does not participate in the performance. They focused on highlighting the ethical side of the interaction between science and society in a play. For the study, 39 students aged 15 to 17 were interviewed after a science theater performance, which dealt with the ethical dilemmas of eating, such as healthy eating and genetic modification. Immediately after the performance, there was a group discussion on the topics. In the interviews, the students mostly focused on the matters outside the themes of the play and things related to the performance technique. However, the students were also able to discuss the content of the play and said that the performance had made them think. The researchers considered this as a promising sign that similar performances could be used to teach about the social and ethical dimensions of science.

Halpern (2009) has also reported audience reactions to science theatre. The noninteractive performance RE: Design is based on the correspondence between Charles Darwin and Asa Gray. Out of the audience of 50 adults, 27 answered a survey and four of the respondents were selected for an interview. Based on the survey and interviews, Halpern stated that the most interesting contents of the play were its historical and philosophical context, narrative factors that helped the audience to understand the concepts, and humanizing of researchers. Two thirds of the respondents stated to have seen traits of researchers' personalities, their human side, or referred to the relationships between researchers. Seeing researchers as human beings and the interaction between researchers are seen as central elements of nature of science (e.g. Abd-El-Khalick et al. 2008). Halpern also reports that the aims of the play were seen differently between 
respondents. The common assumption was that the author wanted to convey certain ideas through the play (e.g. support of evolutionary theory), arouse interest in science or show the human side of the researchers portrayed by the play.

Using science theatre in teaching has not been studied much, and no theoretical framework for it has been created (Ødegaard, 2003). According to Wieringa et al. (2011), the situation is still the same. One reason for few studies is that the topic is on the intersection of science and art. For example, Klassen (2009) has created tools to be used in the analysis of historical narratives. However, producing a good narrative is not possible with these tools. Producing artistic, creative processes with academic analysis is challenging. Wieringa et al. (2011) suppose that the reason for the small amount of studies may be due to the unique nature of the performances. Repeating the same script on different location produces a different performance. For this reason, it is difficult to study the results and draw generalizations. Also in this study the results have to be analyzed considering these limitations.

Ødegaard (2003) has analyzed drama use in science teaching. In Odegaard's twodimensional model, teaching has always a goal that is either concepts, nature of science or interaction between science and society. On the other axis is the nature of drama, which develops from inquiry-based and improvised towards carefully directed and theater-like.

Drama, which aims at teaching concepts and where students themselves perform, is widely used in science teaching. For example, McGregor (2012) describes a project called Dramatic Science, in which teachers of preliminary education have been trained to use drama in science education. The methods include for example spontaneous role-playing and short plays, in which the children perform, for example, pupation of larva or eclosion of butterfly. Also Dorion (2009) refers to drama use in science teaching and states that there are mainly two kinds of situations discussed in the literature: assuming a role of, for example, a molecule in matter or physical simulation, in which the pupils assume the roles of molecules in matter that is changing states. These examples could be referred to as for example drama, in which the students themselves create a performance but which differs from theatre that has separate audience and performers.

\subsection{Nature of science and history of science}

In this research, theatrical performance is studied from the perspective of nature of science. According to McComas et al. (1998), these are some of the central elements of nature of science as listed in their article:

- scientific knowledge while durable, has a tentative character

- scientific knowledge relies heavily, but not entirely, on observation experimental evidence, rational arguments, and skepticism

- scientists require accurate record keeping, peer review and replicability

- scientists are creative

- science is part of social and cultural traditions

- science and technology impact each other 
Osborne et al. (2003) and Bartholomew et al. (2004) have introduced some Ideasabout-Science that should be taught in schools. Their categorization focuses more on the knowledge of nature of scientific and its formation. Nature of science includes:

- scientific methods and critical testing

- science and certainty

- hypothesis and prediction

- creativity

- cooperation and collaboration in the development of scientific knowledge

In their research, Abd-El-Khalick et al. (2007) studied how nature of science was presented in textbooks. The research presented e.g. the following characteristics:

- scientific knowledge is empirical

- science is creative

- scientific knowledge can change

- the myth of scientific method

- social dimensions of science

- social and cultural context of science

Common characteristics for all categorizations mentioned above are:

- presenting the human side of researchers

- collaboration between researchers

- interaction between science and the surrounding world

- aim to portray a more realistic and less straightforward image of scientific process

The history of science is often presented as a context in which teaching about nature of science would be efficient. There are case examples in the history of science in the light of which different elements of nature of science could be scrutinized the way they have actually occurred. For example, Henke et al. (2009) and Höttecke et al. (2012) discuss the aims and methods of European HIPST (History and Philosophy in Science Teaching) project, in which the central medium of information is formed by historical case studies. The aim of the project has been to bring knowledge of epistemology, context and scientific processes into teaching. In the project, nature of science was approached through historical case examples, using versatile and student-oriented approaches. Using drama methods has also been widespread consisting for example mimicking physical systems, metaphorical performances, such as a "human sculpture" depicting a moment in laboratory, and assuming a role of a researcher.

Also, for example in The Story Behind Science project (Clough 2012) historical case examples were chosen as the context for teaching about nature of science. In the project, few-page-long texts of historical events with spaces for notes and reflection have been drafted. Clough suggests that stories like this bring out the human side of people involved in scientific processes and may help in understanding scientific contents as well as help in increasing the understanding of nature of scientific knowledge and situate science in human context. 
Education on nature of science is considered to be an important learning goal. It is regarded to be part of or leading to scientific literacy and it also helps citizens to better understand the role of science in society (see e.g. Lederman 2007). Vesterinen et al. (2009) have also demonstrated that nature of science is clearly present in the National Curricula of Finland, Sweden and Norway, although Höttecke et al. (2011) state that a common conception among teachers participating in HIPST was that in various European countries philosophy of science does not have a central role in the curriculum.

However, there are many obstacles for the use of history as a context for teaching nature of science. Höttecke et al. (2011) focus on physics teaching but the results can most likely be generalized to the teaching of other science subjects as well. According to them, obstacles for utilizing philosophy and history of science in teaching include e.g. teaching culture, the attitudes and competence of teachers as well as curricula and textbooks that do not support discussing history and philosophy in teaching. Forato et al. (2011) have also analyzed obstacles for the use of history and philosophy in teaching. As a result, they have a list of parameters according to which the teaching should be planned. Obstacles for the use of history in teaching are caused by, for example, the need to adjust the historical content to the goals and to consider the effect of leaving out elements from the story has on the portrayed image. The researchers recommend that primary historical sources are used and too linear presentations are avoided, however this approach is often beyond the limited resources of teachers.

\section{Aim of the study}

The aim of the research is to understand the significance of science theatre in teaching and popularization of history of chemistry. The research was guided by three main questions and four subquestions:

1. What is the significance of Virtanen! play according to the audience?

1.1. What does the play portray according to the audience?

1.2. What elements of nature of science the audience sees in the play?

2. How important is the history of Finnish chemistry according to the audience?

2.1. How much the audience knows about the history of Finnish chemistry?

2.2. What is the significance of history of Finnish chemistry to the audience?

3. How history of Finnish chemistry should be brought out according to the audience?

\section{Background of the study}

"Virtanen! -play about scientist's life" was a custom theatrical performance for anniversary seminar of Finland's Science Education Centre LUMA held in autumn 2011. Due to its great success, the play was performed also in three other events. The audiences of the events consisted mainly of professionals from the fields of science, technology, and science teaching. The size of the audience varied approximately from one to two hundred. 
The script of the play was written by a Master of Science in Technology (Chemical), who has previous experience in writing plays. The cast of the play consisted of students of chemistry teacher education, a few of whom had previous experience in acting. The project was carried out on voluntary basis, and no educational, research or artistic goals were set to it.

The script of the play is mainly based on primary sources of information (e.g. interviews with Virtanen's colleagues and family members), as well as contemporary descriptions and previously written extensive histories. The play included only little expert-level information and it did not stress chemical contents significantly. According to the playwright, the focus of the play is on a good story over historical authenticity. On the scale by Beck et al. (2011), the play is placed on research axis near the end of systematic research and on the performance axis the stress is on the aesthetic side.

The performance was approximately 45 -minute-long. The central features of the play were:

- The play begins at the end of Finnish Civil War and continues chronologically towards Nobel-winner Virtanen's retirement.

- Central location is Virtanen's laboratory, where Virtanen's changing research group is present.

- Virtanen's innovations are brought up and various experiments and their results are referred to, including experiments the results of which were proved inaccurate. Virtanen's innovations are also criticized.

- One of the characters is Virtanen's wife, who in the play supports her husband even though he is caught up in work for long periods of time.

- The play includes elements of comedy, e.g. laboratory secretary, who disapproves Virtanen's decision to hire women to work there.

- During the war, Member of Parliament (later president) Kekkonen urges Virtanen to target his research towards the needs of a country in war. The celebrations after Nobel Prize are disrupted by a debate about a statement regarding the Soviet Union.

- Virtanen continues his research until the end of the play. Towards the end, Virtanen refuses to welcome visitors from the Soviet Union in a humorous scene. The play ends in a touching dialogue between Virtanen and his granddaughter.

Before the second and third performance of the play, the playwright interviewed briefly a person who had known the protagonist before the audience.

\section{Method}

This is a case study. After the first two performances, part of the audiences $(\mathrm{N}=45)$ answered a survey via electronic form. Most of the respondents in this first survey represented quarters, such as teacher education unit, that are closely connected with Finland's Science Education Centre LUMA. The answers were in general longer that those given on paper forms. These answers were used to improve the questions and the answers 
were included in the analysis of the data for suitable parts. For example open answers were adapted to answers to multiple-choice questions. Part of the open questions was adapted to multiple-choice questions and part of them were rephrased. The improved version of the survey (see Appendix 1) was handed out to the audience after the third performance. Among the audience of approximately 200 people, 126 answered the survey.

The survey form included multiple-choice and open questions from which the ones related to the research questions of this study were analyzed. The answers to open questions were analyzed using content analysis. Open answers to questions 3.1 and 3.2 were analyzed together because they often referred to the same topic and each other. The research data was first summarized according to central concepts, according to which the contents were categorized. The results are analyzed bearing in mind the limitations caused by the creative and complex processes through which the results have been achieved.

The reliability of the categorization was tested by inter-rater agreement. For this, answers from 30 respondents were chosen at random from the part of the data that did not consist any totally blank forms and included both electronic and paper answers in relation to the whole data. The first inter-rater categorized the answers to questions 3.1 "Describe in few sentences the significance of Virtanen! play" and 3.2 "Describe in few sentences what did you learn from it". The categorization was done by a chemistry teacher student, who was involved in the play. The second inter-rater categorized the answers to question 4 "Describe in few sentences why it would be or would not be important to know about the history of Finnish chemistry or chemical industry." The categorization of the answers to this question was done by a Master of Science, who also was involved in the play. Cohen's Kappa coefficient was calculated to determine the inter-rater agreement. With regard to questions 3.1 and 3.2 the Kappa value was good, o,75. No blank answers were included in the data. The Kappa value for question 4 was 0,73 after blank answers were omitted from the data.

\section{Results}

The audiences can be divided into four main groups based on their occupation. 41 persons from the audience were working or had worked as a researcher in natural sciences, 54 persons were on other positions in the field of science and technology, 24 persons were science teachers or prospective science teachers, and the rest 52 persons did not have any occupational links to science or technology.

Age and gender were not asked from the respondents who filled out the electronic form. In the improved survey, 126 respondents mentioned their age. The average age of these respondents was 52 and the gender ratio was quite even (M/W 56/69). Next, the results are presented and analyzed with regard to the research questions. 


\subsection{Significance of the play}

The first research question is answered by the analysis of answers to open questions 3.1 and 3.2. The content of both questions was coded under one category, and the frequencies are presented in chart 1.

The majority of audience (43\%) felt that the play portrayed Virtanen's life and persona.

"The most important phases in the life of A.I. Virtanen; how the life of a top researcher is similar still today." (answer to question 3.2, paper form 90)

"The play brings out the human side of the life of a noted researcher in a form that the audience can easily chew. I thought it was particularly good that the actors were chemistry students." (answer to question 3.1, electronic form 14)

$19 \%$ of the respondents stated that the play portrayed Virtanen's work.

"How dedicated he was to his work. He studied many different things." (answer to question 3.2, paper form 115)

The theatrical performance was advertised as a play on the history of chemistry, and $16 \%$ of the audience stated that the play was about Finnish history or history in general. $9 \%$ said that the play was about the history of chemistry (or science).

\subsection{Nature of science in theater}

Questions 3.1 and 3.2 do not directly address nature of science but out of the 171 respondents 38 (app. 22\%) brought up issues that can be identified as elements of nature of science. Out of them, 29 respondents (app. 17\% of all respondents) stated something that can be interpreted to be in line with the consensus on nature of science discussed in literature.

10 respondents identified social interaction in the play or the significance of group work in scientific conduct.

"Gave a good picture of a community unique to Finnish research world and work under charismatic, ingenious leader." (answer to question 3.2, electronic form 13)

12 respondents stated that the play depicted scientific conduct.

"Reminds of the significance of Finnish scientific work. Brings out the most important parts of Virtanen's life and his working methods and sacrifices." (answer to question 3.1, paper form 21)

"Apt in depicting how top research is created." (answer to question 3.1, paper form 54)

In addition, 12 respondents stated that the play showed interaction between society and science.

"The impact of politics/war to university work." (answer to question 3.2, paper form 46)

"How A.I. Virtanen worked and it was influenced by the state of the whole world. Virtanen did not work alone but there was a group of researchers and assistants in the background." (answer to question 3.2, electronic form)

The previous remarks are mainly related to the collaboration between protagonist and his closest partner, the end of their collaboration, as well as to wartime, during which the protagonists had to work with explosives and maintaining the food supply. 
Chart 1 The categorization of answers to questions 3.1 and 3.2 and their frequencies

\begin{tabular}{|c|c|c|}
\hline & Description of the category & $f$ \\
\hline $1 \mathrm{~A}$ & $\begin{array}{l}\text { The play gives (general) information and the viewer states to have learned } \\
\text { something. The play is educational and it presents well something (left unclear in the } \\
\text { answer). }\end{array}$ & 11 \\
\hline 1B & $\begin{array}{l}\text { The aim of the play is to bring Virtanen forward, and one can learn something about } \\
\text { him (unclear what). }\end{array}$ & 10 \\
\hline $1 \mathrm{C}$ & $\begin{array}{l}\text { The aim of the play is to bring Virtanen forward and one can learn about Virtanen's } \\
\text { persona, profile/life history. }\end{array}$ & 73 \\
\hline $1 \mathrm{D}$ & $\begin{array}{l}\text { The aim of the play is to bring Virtanen forward and one can learn about Virtanen's } \\
\text { work/career/significance of work or the play popularizes science. }\end{array}$ & 32 \\
\hline $1 \mathrm{E}$ & The aim of the play is to teach and one can learn chemistry contents from it. & 1 \\
\hline $1 \mathrm{~F}$ & $\begin{array}{l}\text { The aim of the play is to depict and bring forward history of Finland (or history in } \\
\text { general), portray a period piece or one can learn about those themes. }\end{array}$ & 27 \\
\hline $1 \mathrm{G}$ & $\begin{array}{l}\text { The aim of the play is to bring forward the history of chemistry or history of } \\
\text { science/industry or one can learn about those themes. }\end{array}$ & 16 \\
\hline 2A & $\begin{array}{l}\text { The play increases interest but it is unclear towards what or the play is interesting } \\
\text { according to the respondent (unclear answers). }\end{array}$ & 8 \\
\hline 2B & $\begin{array}{l}\text { The play increases interest towards Virtanen (in person) or portraying Virtanen's } \\
\text { persona is interesting according to the respondent. }\end{array}$ & 7 \\
\hline $2 \mathrm{C}$ & $\begin{array}{l}\text { The play increases interest towards research / motivates into the field of chemistry } \\
\text { or there is interesting research in the play. }\end{array}$ & 8 \\
\hline $2 \mathrm{D}$ & The play increases interest in history (of chemistry). & 6 \\
\hline $3 \mathrm{~A}$ & $\begin{array}{l}\text { The play demonstrates the social interaction and group work among scientists or the } \\
\text { significance of the research group and assistants in scientific work. }\end{array}$ & 10 \\
\hline 3B & The play depicts scientific work/method (then and now). & 12 \\
\hline $3 \mathrm{C}$ & The play demonstrates the human side of scientists. & 4 \\
\hline $3 \mathrm{D}$ & $\begin{array}{l}\text { The play brings forward the work-related dedication, passion and sacrifices of } \\
\text { Virtanen/scientists or the remarkable efforts required for scientific achievement. }\end{array}$ & 12 \\
\hline $3 \mathrm{E}$ & $\begin{array}{l}\text { Society-science interaction: The play depicts, how society/politics/people outside } \\
\text { science can try and influence the scientific conduct or how scientists influence matters of } \\
\text { society, politics and wellbeing. }\end{array}$ & 10 \\
\hline $3 \mathrm{~F}$ & $\begin{array}{l}\text { Science-technology interaction: The play demonstrated how technology influences } \\
\text { science or how the development of science influences technological innovations. }\end{array}$ & 1 \\
\hline 4 & The play is a tribute to Virtanen or introduces the important chemist/achievement. & 22 \\
\hline 5 & Overall positive comment, nothing more to code. & 10 \\
\hline 6 & $\begin{array}{l}\text { One could not learn anything from the play or the respondent states that the } \\
\text { depicted matters were familiar to him/her. }\end{array}$ & 5 \\
\hline 8 & The answer includes meaningful text that does not fit any categories above. & 4 \\
\hline 9 & Blank/no meaningful text & 23 \\
\hline
\end{tabular}


Another theme that rose from the answer data was that the play depicted exceptional dedication or sacrifice of scientists to their work. This "romanticized" view came up in 12 answers.

"The play presents well the passion of researchers towards their works." (answer to question 3.1 , electronic form 23)

"One must immerse oneself completely in science." (answer to question 3.2, paper form 119)

The answers depicting nature of science were divided unevenly according to respondents' occupation. In the small occupational group of teachers and student teachers over half of the respondents identified contents related to nature of science but also in other groups $15 \%$ to $20 \%$ had brought up these conceptions.

\subsection{Knowledge of Finnish history}

The majority of respondents (101/171) felt they knew something about the life of the protagonist (choosing the middle alternative from three options). From the respondents with background in research, considerably larger amount felt they knew Virtanen's life well in advance (choosing the first alternative from three options). Most of the respondents $(112 / 171)$ felt that history of Finnish chemistry was quite familiar to them in advance (choosing the middle alternative from three options). The majority (101/171) felt that Finns in general know about history of Finnish chemistry only little (the second smallest alternative on the scale of one to four).

In question 5, the audience was asked how much history of chemistry should be brought out in future. On four point scale, 106 respondents from 171 chose the alternative b (little more) and 51 chose alternative a (considerably more).

The fact that the audience had come to see the performance on history of science on their own initiative have to be taken into consideration in evaluation of the results. However, the results from the group representing people with non-scientific occupational background were quite similar. The life of the protagonist and history of chemistry were less familiar to the respondents in this group. The interest towards the history of chemistry in question 5 was on average as high among all respondents and in the group representing the part of the audience with non-scientific background.

\subsection{Significance of knowledge of history of Finnish chemistry}

In the survey, the main question was about the significance of knowledge of Finnish history of science. In seven answers, knowledge of history of Finnish chemistry was not regarded important to wide audience or in all occupations. The answers suggest that there are various reasons why knowledge of history of Finnish chemistry is considered important. The justifications are presented in chart 2.

The most common answer (26) stated that the knowledge of history is important in its own right, without any stated instrumental value. 14 respondents justified the importance 
Chart 2 The categorization of answers to question 4 and frequencies of categories

\begin{tabular}{|l|l|l|}
\cline { 2 - 3 } \multicolumn{1}{l|}{} & Description of the category & $f$ \\
\hline $1 \mathrm{~A}$ & $\begin{array}{l}\text { Knowledge of history is part of all-round education or "good to know" or otherwise } \\
\text { important but the importance is justified weakly. }\end{array}$ & 26 \\
\hline $1 \mathrm{~B}$ & $\begin{array}{l}\text { Knowledge of history of (chemistry or) chemical industry is important because of the } \\
\text { field's important (economical) role, emphasis on industrial and societal aspects. }\end{array}$ & 14 \\
\hline 1C & $\begin{array}{l}\text { Knowledge of history of chemistry (or chemical industry) is important because chemistry } \\
\text { has an impact on the wellbeing and society, emphasis on mundane and humane } \\
\text { aspects. }\end{array}$ & 5 \\
\hline $1 \mathrm{D}$ & $\begin{array}{l}\text { Unclearly stated “continuum" of history or better understanding of the } \\
\text { current state/appreciation through history. }\end{array}$ & 17 \\
\hline $1 \mathrm{E}$ & $\begin{array}{l}\text { Knowledge of history is believed to increase the appreciation of chemistry, increase } \\
\text { interest towards chemistry or increase the visibility of chemistry. }\end{array}$ & 10 \\
\hline $1 \mathrm{~F}$ & $\begin{array}{l}\text { Knowledge of history can motivate into studying or pursuing a career in science, } \\
\text { for example by providing the youth with role models. }\end{array}$ & 18 \\
\hline $1 \mathrm{G}$ & $\begin{array}{l}\text { Knowledge of history helps to learn/understand science of today and can help in } \\
\text { the development of science of tomorrow. }\end{array}$ & 3 \\
\hline $1 \mathrm{H}$ & $\begin{array}{l}\text { Knowledge of history (of chemistry) is important because it supports national self- } \\
\text { esteem or improves (own or others') perception of Finland and Finns. }\end{array}$ & 18 \\
\hline $1 \mathrm{I}$ & $\begin{array}{l}\text { Better knowledge of history (of chemistry) would advance the function of research } \\
\text { (or industry) in society. }\end{array}$ & $\begin{array}{l}\text { Knowledge of the history (of chemistry) is not important to wide audience, in } \\
\text { everyday life, to most occupational groups or no one. }\end{array}$ \\
\hline 8 & \begin{tabular}{l} 
"None of the above" code, if the answer does not fit any of the categories above \\
\hline 9
\end{tabular} & 16 \\
\hline Blank/no meaningful text \\
\hline
\end{tabular}

of knowledge of history of chemistry by the central role of chemical industry in Finland and five respondents mentioned the important role of chemistry in everyday life, but did not state any instrumental value to chemistry knowledge.

"It is good and mind broadening to know about the history of all fields, including chemistry." (paper form 54, category $1 \mathrm{~A}$ )

"It is part of all-round education to know about the past, chemistry is important part of the culture of natural sciences." (electronic form 11, category $1 \mathrm{~A}$ )

17 respondents justified the importance of knowledge of history by its instrumental value that was somewhat unclear in the answer. 10 respondents felt that better knowledge of chemistry history would increase the appreciation of the field of chemistry. 
"Without history the nation doesn't have future either." (paper form 56, category 1D)

"Science is valuable, knowledge of history creates interest also towards the future

development of science. All-round education!" (paper form 23, categories $1 \mathrm{~A}$ and $1 \mathrm{E}$ )

Part of the respondents stated that there is clear instrumental value in knowing about history. The significance on motivation to study science and career choices was also mentioned (18) and the significance to national self-esteem and image was mentioned 18 times.

"Knowledge of history would be important because through that one can get motivation, role models, and important feeling of being part of a continuum." (paper form 14, category $1 \mathrm{~F}$ )

"It would raise Finnish self-esteem if accomplishments would become more widely known -> further increase interest towards the field and increase the number of students/researchers." (paper form 21, categories $1 \mathrm{~F}$ and $1 \mathrm{H}$ )

\subsection{Contents and methods of history of Finnish chemistry}

In question 6, the respondents were asked, which themes of history of chemistry they would like to know more of. The answers emphasized the lives of historically important individuals, eras/trajectories/timelines and innovations/most important achievements in Finland (46\%, 33\% and 57\% of respondents). Chemical industry in Finland was mentioned fewer times than other aspects related to Finland (18\%). Equivalent categories related to other countries were less popular $(5 \%-19 \%)$, and the chemical industry in other countries was considered the least interesting.

In question 8, the audience was asked in which mediums they would like history of chemistry to be brought up. The most popular mediums were theater (65), school teaching (68), and documentary films (74) that were followed by exhibitions (42). The fact that the question was asked from theater audience naturally explains the popularity of theater in the answers.

When the audience was asked, how the history of chemistry should be brought up in school teaching, the alternative "Together with chemistry contents" was the most popular answer (71). "During separate lessons on history of science" was half as popular by 35 mentions. Also "In form of theater" (56), "In collaboration between subjects" (45) and "Through individual histories" (57) were commonly chosen alternatives. Answers are categorized based on the occupation of the respondent in chart 3 .

Alternative "As an additional theme that will be discussed if there is extra time" was not popular (4 mentions), but neither was "As compulsory content that should be added into the curriculum" (7 mentions). "During history lessons, not during chemistry lessons" was chosen only twice among researchers, but every fifth member of the audience with other scientific occupation and every sixth person with non-scientific occupation was in favor of this alternative. 
Chart 3 The answers to question 9 and their respective frequencies according to occupational group

\begin{tabular}{|c|c|c|c|c|c|c|c|c|c|c|c|c|c|}
\hline & & \multicolumn{12}{|c|}{\begin{tabular}{|llll}
$\begin{array}{l}\text { History of } \\
\text { handled... }\end{array}$ & chemistry & should & be \\
\end{tabular}} \\
\hline & & 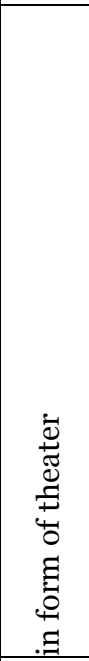 & 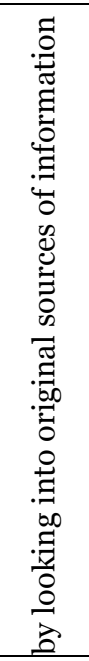 & 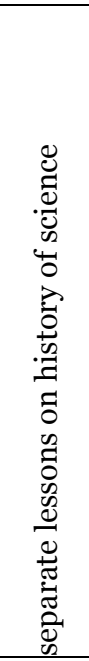 & 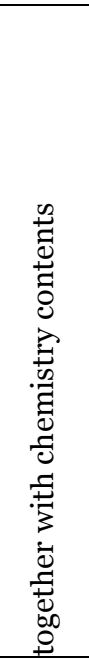 & 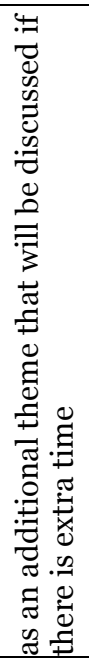 & 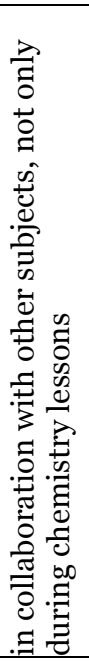 & 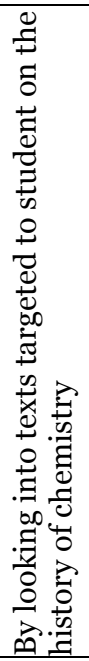 & 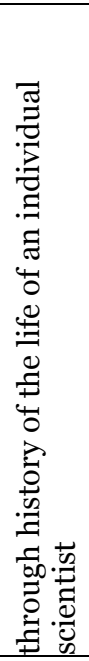 & 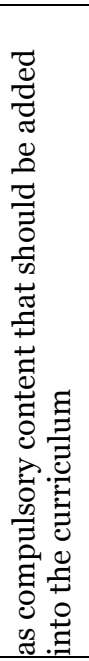 & 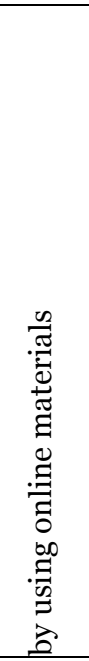 & 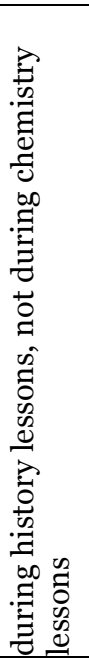 & 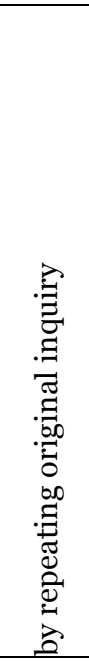 \\
\hline researcher & $\mathrm{N}=41$ & $24 \%$ & $12 \%$ & $24 \%$ & $49 \%$ & o\% & $27 \%$ & $2 \%$ & $46 \%$ & $5 \%$ & $24 \%$ & $5 \%$ & $15 \%$ \\
\hline $\begin{array}{l}\text { other scientific } \\
\text { occupation }\end{array}$ & $\mathrm{N}=54$ & $30 \%$ & $19 \%$ & $20 \%$ & $48 \%$ & $4 \%$ & $33 \%$ & $6 \%$ & $30 \%$ & $4 \%$ & $33 \%$ & $20 \%$ & $15 \%$ \\
\hline teacher & $\mathrm{N}=24$ & $29 \%$ & O\% & $8 \%$ & $13 \%$ & o\% & $13 \%$ & $4 \%$ & $8 \%$ & o\% & $8 \%$ & $4 \%$ & $13 \%$ \\
\hline $\begin{array}{l}\text { non-scientific } \\
\text { occupation }\end{array}$ & $\mathrm{N}=52$ & $44 \%$ & $25 \%$ & $23 \%$ & $42 \%$ & $4 \%$ & $25 \%$ & $10 \%$ & $38 \%$ & $6 \%$ & $17 \%$ & $15 \%$ & $35 \%$ \\
\hline total & $N=171$ & $33 \%$ & $16 \%$ & $20 \%$ & $42 \%$ & 2\% & $26 \%$ & $6 \%$ & $33 \%$ & $4 \%$ & $23 \%$ & $13 \%$ & $20 \%$ \\
\hline
\end{tabular}

\section{Conclusions}

Based on the results, the audience saw the theatrical performance Virtanen! mainly as a history of the life of an individual scientist. Virtanen's persona and individual life were emphasized in many of the answers, which is in line with Halpern's (2009) results, according to which the audience of a similar performance had seen the story as namely focusing on the protagonist.

Scientific conduct that rose spontaneously from the answers suggests that apart from the individual portrait, according to many members of the audience the play also depicted nature of science. This is particularly interesting as it was not set as a goal for the script, the audience was not explicitly asked about it and the audience consisted in large part of people with connections to natural sciences. Most of the particular elements that were brought up are part of the general consensus on nature of science and included: the social dimension of scientific work and the interaction of science and society as well as scientific conduct in general.

However, at the same time it was noticed that drama could create an overly romanticized image of the work of a researcher. The conception of researchers, who have to sacrifice some parts of their normal life can repel youth from pursuing a career in science. 
Allchin (2003) has warned against creating these kinds of myths. To avoid mythical conceptions, the writer of history of science has to be conscious of them and avoid narrative effects that can create such myths.

The audience of the play was quite mature, but it might still be safe to assume that also younger audience, pupils and students, would find similar themes in the play than the older audience. The results support using traditional theater in teaching, in addition to drama, role-playing and interactive theater. In formal teaching, it would be necessary to link the performance to explicit and reflective teaching, which is recommended by Rudge \& Howe (2009) in teaching of nature of science before and after the performance. The observations of nature of science suggest that plays could be used to teach contents that are traditionally considered as difficult to teach, if historical accuracy is taken into consideration in the production of the play.

The reason why history is not used in science education is mostly due to the teachers' lack of resources (e.g. Forato et al. 2011). Preparing a science theater performance using multiple sources of primary information is demanding for teachers and students. However, having professionals prepare science theater outside school and organizing performances in schools could offer a possibility to bring out the history of science at schools while preserving most of the benefits of historical approach.

Based on this study, bringing science theater to schools was supported by the audience, even though the opinions were mixed. When the audience was asked about presenting history of chemistry at schools, many respondents wanted to include history of chemistry in chemistry lessons and many even wanted separate lessons of science history. General opinion was that history of chemistry should be neither compulsory in curriculum nor an additional theme.

According to their own estimate, the audience did not know the history of chemistry very well and considered the general level of knowledge lower than their own. On the other hand, the audience represented mainly professionals from the fields of science and technology and thus the sample can be regarded to have increased knowledge of the subject. Despite of this and Virtanen's Nobel Prize, the audience did not feel they knew him well. Even among teachers and scientists, the knowledge of history of chemistry was not good according to their own estimate.

Information on the history of chemistry was considered interesting even among those with non-scientific occupations. The audience had come to see the play on history of chemistry on their own initiative; therefore the results cannot be directly generalized to concern wide audience. However, the answers suggest why they consider history important. The majority of answers were concerned with all-round education or other unclear justification. Based on the opinions of the audience, information on the history of chemistry could also motivate into studying the subject and might improve national self-esteem, which in particular could be linked to interest in the history of Finnish chemistry. 
The results of the study suggest that particularly regional or national history of chemistry is considered interesting. Based on the results, it would be recommended to approach the history of chemistry could be part of chemistry education at all levels. It also could improve the public image of chemistry.

\section{References}

Abd-El-Khalick, F., Waters, M., \& Le, A. P. (2008). Representations of nature of science in high school chemistry textbooks over the past four decades. Journal of Research in Science Teaching, 45(7), 835-855. doi: http://dx.doi.org/ 10.1002/tea.20226

Allchin, D. (2003). Scientific myth-conceptions. Science Education, 87(3), 329-351. doi: http:///dx.doi.org/ 10.1002/sce.10055

Bartholomew, H., Osborne, J., \& Ratcliffe, M. (2004). Teaching students “ideas-about-science”: Five dimensions of effective practice. Science Education, 88(5), 655-682. doi: http://dx.doi.org/10.1002/sce.10136

Beck, J. L., Belliveau, G., Lea, G. W., \& Wager, A. (2011). Delineating a spectrum of research-based theatre. Qualitative Inquiry, 17(8), 687-700. doi: http://dx.doi.org/ 10.1177/1077800411415498

Clough, M. P. (2011). The story behind the science: Bringing science and scientists to life in postsecondary science education. Science \& Education, 20(7), 701-717. doi: http://dx.doi.org/ 10.1007/s11191-010-9310-7

Dorion, K. R. (2009). Science through Drama: A multiple case exploration of the characteristics of drama activities used in secondary science lessons. International journal of science education 31 (16) 2247-2270. http://dx.doi.org/ 10.1080/09500690802712699

Forato, T. C. D. M., de Andrade Martins, R., \& Pietrocola, M. (2012). History and Nature of Science in High School: Building Up Parameters to Guide Educational Materials and Strategies. Science \& Education, 1-26. doi: http://dx.doi.org/10.1007/s11191-011-9419-3

Halpern, M. (2009). Understanding how audiences understand science on stage: Cultural context in the dramatization of Darwin's letters. doi: http://meganhalpern.com/Halpern_2008_UnderstandingAudiences.pdf (17.3.2013)

Henke, A., Höttecke, D., \& Rieß, F. (2009, June). Case studies for teaching and learning with history and philosophy of science: Exemplary results of the HIPST project in Germany. In Tenth International History, Philosophy, Sociology \& Science Teaching Conference (IHPST), South Bend, USA (pp. 24-88). osoitteesta: http://www3.nd.edu/ ihpsto9/papers/Henke_MS.pdf

Höttecke, D., Henke, A., \& Riess, F. (2012). Implementing history and philosophy in science teaching: Strategies, methods, results and experiences from the European HIPST project. Science \& Education, 1-29. doi: http://dx.doi.org/10.1007/s11191-010-9330-3

Höttecke, D., \& Silva, C. C. (2011). Why implementing history and philosophy in school science education is a challenge: an analysis of obstacles. Science \& Education, 2O(3), 293-316. doi: http://dx.doi.org/ 10.1007/s11191-010-9285-4

Kerby, H. W. et al. (2010). Fusion science theater presents The amazing chemical circus: a new model of outreach that uses theater to engage children in learning. Journal of chemical education, 87(10) 1024-1030. doi: http://dx.doi.org/10.1021/ed100143j

Klassen, S. (2009). The construction and analysis of a science story: A proposed methodology. Science \& Education, 18(3), 401-423. doi: http://dx.doi.org/10.1007/s11191-008-9141-y

Lederman, N. G. (2007). Nature of science: Past, present and future. In N. G. Lederman \& S. Abell (ed.), Handbook of research on science education (831-879). Mahwah, NJ: Lawrence Erlbaum Associates.

McComas, W. F., Almazroa, H., \& Clough, M. P. (1998). The nature of science in science education: An introduction. Science \& Education, 7(6), 511-532. doi: http://dx.doi.org/ 10.1023/A:1008642510402 
McGregor, D. (2012). Dramatising science learning: Findings from a pilot study to re-invigorate elementary science pedagogy for five- to seven-year-olds. Journal of Science Education, 34(8), 1145-1165. doi: http://dx.doi.org/10.1080/09500693.2012.660751

Odegaard, M. (2003). Dramatic science. A critical review of drama in science education. Studies in science education, 39, 75-102. doi: http://dx.doi.org/ 10.1080/03057260308560196

Osborne, J. et al. (2003). What "Ideas-about-science" should be taught in school science? A Delphi study of the expert community. Journal of research in science teaching, 4O(7) 692-720. doi: http://dx.doi.org/ 10.1002/tea.10105

Peleg, R. \& Baram-Tsabari, A. (2011). Atom surprise: Using theatre in primary science education. Journal of Science Education and Technology, 20, 508-524. doi: http://dx.doi.org/10.1007/s10956-011-9299-y

Rudge, D. W., \& Howe, E. M. (2009). An explicit and reflective approach to the use of history to promote understanding of the nature of science. Science \& education, 18(5), 561-580. doi: http://dx.doi.org/10.1007/s11191-007-9088-4

Vesterinen, V. M., Aksela, M., \& Sundberg, M. R. (2009). Nature of chemistry in the national frame curricula for upper secondary education in Finland, Norway and Sweden. NorDiNa. (http://hdl.handle.net/10138/28561)

Wieringa, N. F., Swart, J. A. A., Maples, T., Witmondt, L., Tobi, H., \& van der Windt, H. J. (2011). Science Theatre at School: Providing a context to learn about socio-scientific issues. International Journal of Science Education, Part B, 1(1), 71-96.doi: http://dx.doi.org/10.1080/21548455.2010.544090 


\section{Appendix 1}

\section{Survey}

The aim of the survey is to get information on the significance of Virtanen! play as well as the need and significance of bringing out the culture and history of Finnish chemistry. The survey is part of research project on teaching the history of science by Unit of Chemistry Teacher Education, Department of Chemistry, University of Helsinki. Your answers are very important from the perspective of the subject and follow-up. You may answer anonymously. Thank you for your answers.

\section{Background information}

1.1. gender: male / female

1.2. age:

1.3. background in science: (circle the best alternative)
a) I am or have been a researcher in chemistry
b) I am a chemistry teacher at school
c) I have other job in the field of chemistry
d) I am prospective chemistry teacher
e) I am prospective researcher in chemistry
f) I am a researcher in another field of natural sciences
g) I have other job in the field of natural science or technology
h) My work or studies are not related to natural sciences
i) Something other, please specify

\section{History of Finnish Chemistry}

2.1. Before the play, the life of Nobel-winner Virtanen was for me: (circle the best alternative)
a) very familiar
b) little familiar
c) not at all familiar

The history of Finnish chemistry is for me: (circle the best alternative)
d) very familiar
e) little familiar
f) not at all familiar

2.2. I think that among Finns, the history of Finnish chemistry (from $18^{\text {th }}$ Century to this date) is: (circle the best alternative)
a) very familiar
b) quite familiar 
c) little familiar

d) not at all familiar

3. Virtanen! play

3.1. Describe in few sentences the significance of Virtanen! play:

3.2. Describe in few sentences what did you learn from it:

3.3. Describe in few sentences how the play could be developed in future:

4. Describe in few sentences why it would be or would not be important to know about the history of Finnish chemistry or chemical industry:

5. Compared to the current situation, how much history of Finnish chemistry or chemical industry should be brought out in future (circle the best alternative)
a) considerably more
b) little more
c) it is brought out enough
d) something other, please specify?

6. What would you hope to learn about the history of chemistry (choose max. three)
a) histories of the lives of individual Finnish scientists
b) eras/timelines/trajectories from Finland
c) innovations/greatest achievements from Finland
d) information on the chemical industry in Finland
e) histories of the lives of individual scientists in other countries
f) timelines/trajectories from other countries
g) innovations/greatest achievements from other countries
h) information on the chemical industry in other countries
i) something other, please specify

7. What themes of history of chemistry have been handled already too much?

8. Which would be the best mediums to bring out history of chemistry? (choose max. three)
a) presentations
b) exhibitions
c) literature
d) theater
e) websites
f) school teaching
g) press 
h) documentary films

i) televised films

j) something other, please specify

9. If history of chemistry would be brought out more in school teaching, how it should be handled in your opinion? Please circle the alternatives you agree with.

History of chemistry should be handled...
a) .... in form of theater
b) ... by looking into original sources of information
c) ... separate lessons on history of science
d) ... together with chemistry contents
e) ... as an additional theme that will be discussed if there is extra time
f) ... in collaboration with other subjects, not only during chemistry lessons
g) ... by looking into texts targeted to student on the history of chemistry
h) ... through history of the life of an individual scientist
i) ... as compulsory content that should be added into the curriculum
j) ... by using online materials
k) ... during history lessons, not during chemistry lessons
l) ... by repeating original inquiry

10. Other suggestions on how you would hope history of science to be dealt with in school teaching?

11. Other comments on the play, arrangements etc.

Warm thank you for your time! 